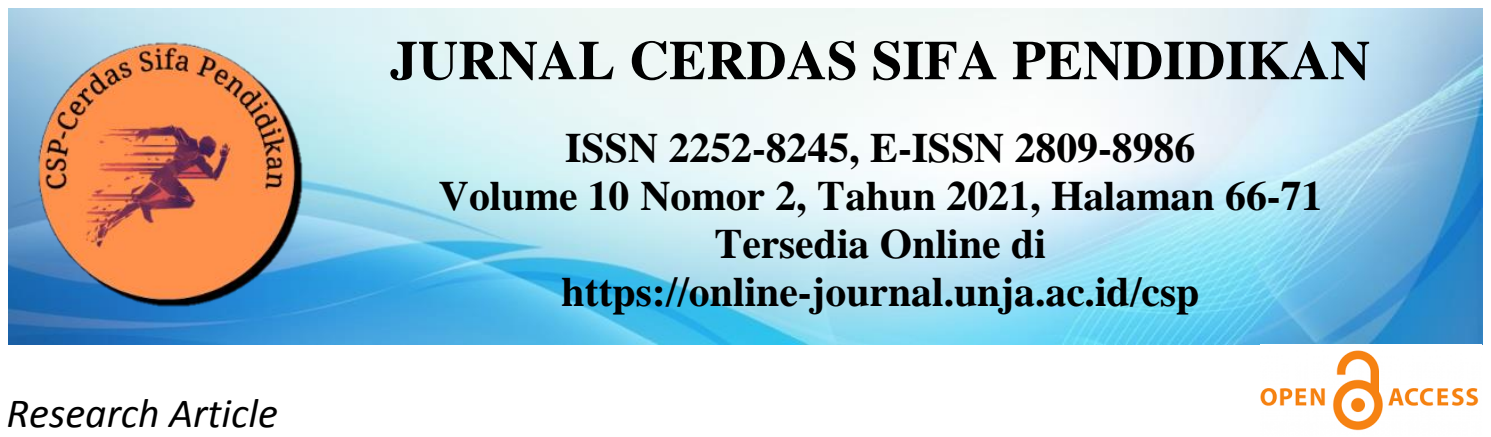

\title{
Sportpreneurship Sebagai Peluang Kewirausahaan Bagi Mahasiswa
}

\author{
Palmizal. $A^{1}$, Ade Setiowati ${ }^{2}$ \\ Program Studi PORKES, FKIP , Universitas Jambi, Indonesia ${ }^{12}$ \\ Correspondence Author : adesetiowati@unja.ac.id
}

\begin{abstract}
ABSTRAK
Pelatihan sportpreneurship akan mampu menjabarkan ilmu dalam ranah teoritis lebih terfokus ke ranah praktis. Penjabaran teori sportpreneurship menjadi ranah praktis memerlukan penguatan yang cukup untuk menciptakan insan yang betul-betul tangguh dalam menjalankan wirausaha. Sasaran utama dalam pemberian motivasi tersebut adalah generasi muda yang mempunyai potensi yang besar untuk memulai usaha baru dan mengembangkanya di masa depan sehingga mempunyai multiplayer effect yang besar dalam penciptaan lapangan kerja baru. Pengangguran adalah masalah kita bersama dan tanggungjawab pemerintah untuk menciptakan iklim usaha bagi penganggur terdidik. Kesempatan membuka usaha memang terpulang bagi terdidik yang belum bekerja. Kesempatan selalu terbuka untuk berwirausaha, baik perorangan maupun kelompok. Pemberian wawasan mengenai berfikir kreatif, inovatif dan visioner di era global untuk membekali mahasiswa mengenai pentingnya berfikir kteatif, inovatif dan visioner serta agar peserta dapat membuka dan mengembangkan cakrawala berfikirnya bahwa segala sesuatu apapun dapat dimanfaatkan menjadi peluang usaha apabila dapat membaca situasi dan kondisi yang ada disekitar.
\end{abstract}

Kata kunci: Sport preneurship. kewirausahaan

\section{Sportpreneurship as an Entrepreneurial Opportunity for Students}

\begin{abstract}
ABSTRACK
Sportpreneurship training will be able to describe science in the theoretical realm more focused into the practical realm. The description of sport preneurship theory into a practical realm requires sufficient reinforcement to create people who are really resilient in running an entrepreneur.The main target in providing motivation is the younger generation who have great potential to start a new business and develop it in the future so that it has a big multiplayer effect in the creation of new jobs. Unemployment is our common problem and the government's responsibility to create a
\end{abstract}


business climate for the educated unemployed. The opportunity to open a business is indeed home for educated people who have not worked. Opportunities are always open for entrepreneurship, both individuals and groups. If there is a will, opportunities are open.Based on the above reality, it is necessary to conduct sport preneurship training as an entrepreneurial opportunity for Jambi University students. Providing insight into creative, innovative and visionary thinking in the global era to equip students about the importance of thinking creatively, innovatively and visionary and so that participants can open and develop cakawala thinking that everything can be used as a business opportunity if they can read the situation and conditions around.

\section{Keywords: Sport preneurship, Entrepreneurship}

\section{PENDAHULUAN}

Pengangguran dan kemiskinan hingga saat ini merupakan masalah besar bangsa Indonesia yang belum bisa terpecahkan. Jumlah penganggur tersebut diperkirakan akan bertambah dengan adanya krisis keuangan global sebesar 20 juta orang sehingga dari jumlah penganguran di tahun sebelumnya sebesar 190 juta orang, akan bertambah menjadi 210 juta orang di tahun 2020. Mengingat data pengangguran pemuda masih cukup tinggi, apabila tidak memperoleh perhatian yang serius mengakibatkan masalah sosial yang cukup tinggi pula.

Faktor-faktor yang menyebabkan terjadinya pengangguran di Indonesia, antara lain: Pertama, jumlah pencari kerja lebih besar dari jumlah peluang kerja yang tersedia (kesenjangan antara supply and demand). Kedua, kesenjangan antara kompetensi pencari kerja dengan kompetensi yang dibutuhkan oleh pasar kerja (mis-match), Ketiga, masih adanya anak putus sekolah dan lulus tidak melanjutkan yang tidak terserap dunia kerja/berusaha mandiri karena tidak memiliki keterampilan yang memadai (unskill labour), Keempat, terjadinya pemutusan hubungan kerja (PHK) karena krisis global, dan Kelima, terbatasnya sumber daya alam di kota yang tidak memungkinkan lagi warga masyarakat untuk mengolah sumber daya alam menjadi mata pencaharian. Dari kelima faktor tersebut, faktor pertama, kedua dan ketiga merupakan faktor dominan yang menyebabkan pengangguran di Indonesia. Dari gambaran tersebut di atas maka perlu dikembangkan program-program kewirausahaan pemuda dalam rangka mempercepat penurunan angka pengangguran.

Untuk mengatasi pengangguran maka pemerintah melaksanakan dengan dua jalur solusi, yaitu Pendidikan Formal yang salah satunya diberikan pelayanan melalui pengabdian kepada masyarakat yang dilakukan oleh dosen-dosen di perguruan tinggi. Kedua, Program Kewirausahaan Pemuda deangan cara untuk memberikan kesempatan belajar (langsung) bagi pemuda usia produktif agar memperoleh pengetahuan, keterampilan, dan menumbuhkembangkan jiwa kewirausahaan yang ditopang oleh sikap mental kreatif, inovatif, profesional, bertanggung jawab, serta berani menanggung resiko dalam mengelola potensi diri dan lingkungannya sebagai bekal untuk peningkatan kualitas hidupnya.

Dalam rangka mengembangkan kewirausahaan pemuda maka perlu terus dihimpun berbagai input pemikiran baik dari kalangan akademisi maupun praktisi kewirausahaan agar implementasi program dan kegiatan bidang kewirausahaan pemuda berjalan pada relnya atau tidak keluar dari substansi dan paradigma kewirausahaan pemuda. Karena itu, perlu dilakukan rapat kerja yang menghimpun para pakar dan 
praktisi kewirausahaan untuk mengkaji perkembangan pelaksanaan kewirausahaan pemuda,khusunya mahasiswa.

Penganggguran dan kemiskinan hingga saat ini merupakan masalah besar bangsa Indonesia terlebih setelah negara kita juga kena imbas krisis keuangan global. Pembangunan industri adalah bagian integral pembangunan ekonomi yang harus dijalankan terpadu dan berkelanjutan sehingga bermanfaat besar bagi masyarakat. Arti penting perindustrian terhadap perkembangan ekonomi tertuang dalam undang-undang No 25 tahun 2001 tentang program pembangunan ekonomi nasional mengamanatkan peningkatan daya saing global dirumuskan lima strategi: pengembangan ekspor, pengembangan industri, penguatan institusi pasar, pengembangan pariwisata dan peningkatan ilmu pengetahuan dan teknologi.

Kewirausahaan adalah proses menciptakan sesuatu nilai yang berbeda dengan mencurahkan waktu dan upaya yang diperlukan, memikul resiko-resiko finansial, psikis dan sosial yang menyertai, serta menerima penghargaan /imbalan moneter dan kepuasan pribadi. Seorang wirausaha harus mampu menciptakan sesuatu yang baru dan berbeda (ability to create the new and different). Kewirausahaan merupakan penerapan kreativitas dan keinovasian untuk memecahkan permasalahan dan upaya memanfaatkan peluang-peluang yang dihadapi orang setiap hari.

Perguruan tinggi merupakan salah satu bagian dari pemerintah yang dinaungi oleh Kemenristek Dikti memiliki tanggung jawab dalam mengembangkan industri olahraga dari sudut pandang ilmiah termasuk didalamnya Universitas Jambi yang memiliki salah satu Fakultas Ilmu Keolahragaan. Mahasiswa yang merupakan bagian dari pemuda, memiliki potensi besar serta kemampuan sebagai ujung tombak dalam melakukan usaha, yang didukung dengan langkah-langkah terstruktur oleh stakeholder (Pemegang Kebijakan) untuk menjadikan industri olahraga yang kompetitif dan professional. "untuk memajukan industri olahraga memang harus memiliki sinergis antara semua pihak, baik pemerintah, pemerintah daerah maupun swasta.

Menurut Sugiono (2011:17) populasi adalah wilayah generalisasi yang terdiri dari objek/subjek yang mempunyai kualitas dan karakteristik tertentu yang ditetapkan oleh peneliti untuk dipelajari dan ditarik kesimpulannya. Populasi dalam penelitian ini adalah mahasiswa semester 1 prodi kepelatihan olahraga Universitas Jambi.

Sampel yang akan digunakan dalam penelitian ini adalah total sampling yaitu dimana keseluruhan anggota populasi memungkinkan atau memiliki kesempatan untuk menjadi sampel. Sampel adalah. mahasiswa semester 1 prodi kepelatihan olahraga Universitas Jambi yang berjumlah 54 orang.

\section{METODE}

Kegiatan ini dikemas dalam bentuk sosialisasi dan penyuluhan. Dalam penyampaian berbagai materi kegiatan dilakukan dengan cara sebagai berikut: pertama disampaikan ceramah, kemudian dilanjutkan dengan diskusi dan diskusi kelompok, selanjutnya akan dilaksanakan praktek pemberian latihan sportpreneurship bagi mahasiswa.

Entrepreneur/ pengusaha seharusnya mempunyai pola pikir yang positif di setiap langkahnya untuk menuju kesuksesan. Apalagi untuk seorang entrepreneur muda yang masih mencoba hal-hal baru. Mindset/ logika dasar yang harus di mengerti oleh entrepreneur yang sifatnya benar ada 5 yang harus di ketahui, yaitu : 
1. Jangan pernah meremehkan yang kecil.

Sekecil apapun usaha/ bisnis kita jangan pernah meremehkannya, sesuatu yang besar berasal dari yang kecil, sesuatu yang kecil dulunya tidak ada. Jangan malu untuk menunjukan usaha kita walau sekecil apapun. Tunjukan pada orang lain dan besarbesarkan kepada publik, dengan begitu kita sudah berinvestasi untuk menjadi suatu perusahaan yang besar yang diketahui banyak orang.

2. Jangan tertawakan mimpi besar.

"Mimpilah setinggi langit asal kaki masih di bumi". Sesuatu memang di awali dari mimpi, jangan pernah takut untuk mimpi besar. Dengan impian besar, kita bisa termotivasi untuk terus berjalan menggapai mimpi tersebut. Hati-hatilah jangan pernah tertawakan mimpi besar anda tersebut karena suatu saat mimpi anda akan terwujud.

3. Jangan mencari pekerjaan.

Ketika kita masih di posisi fresh graduatel penganguran. Jangan pernah mempunyai pemikiran untuk mencari pekerjaan. Tapi pola pikir yang seharusnya kita pakai adalah "Ciptakanlah Pekerjaan". Sengangur apapun jika kita sudah berpola pikir seperti itu maka kita akan mempunyai inisiatif untuk melakukan perkerjaan yang membuat anda sukses dengan pekerjaan tersebut.

4. Mengapa anda keluarkan uang untuk orang lain?

Pertanyaan mudah untuk di jawab "Untuk mencukupi kebutuhan kita". Jika begitu, bagaimana kalau kita yang memberikan pertanyaan tersebut untuk orang lain. "Mengapa orang lain keluarkan uang untuk saya?" karena untuk mencukupi kebutuhan mereka. Apa aja kebutuhan mereka? Kita cari saja apa kebutuhan yang mereka inginkan. Dengan begitu timbul pemikiran untuk menciptakan kebutuhan orang lain, sehingga orang lain bersedia mengeluarkan uang untuk kita.

5. Modal bukan harus selalu uang.

Pemikiran yang tidak selalu dibenarkan untuk memulai sebuah usaha. Banyak jalan untuk memulai usaha tanpa uang. Banyak perusahaan besar dunia di awali tanpa modal. Mereka hanya memanfaatkan situasi atau jasa orang lain dengan melihat peluang untuk di jadikan sebuah hal yang menghasilkan. Berikut merupakan modal/ sumber daya yang harus di ketahui untuk berwirausaha :

a. Uang/ Dana.

Hal pertama yang pasti di pikirkan seorang wirausaha, tapi ini bukan segalanya.

b. Fasilitas.

Kita bisa memanfaatkan fasilitas yang ada di sekitar kita untuk di jadikan sebuah usaha.

c. Tempat Usaha.

Tempat apapun bisa di jadikan sebuah tempat untuk memulai usaha, seperti kostkostan misalnya, kita bisa memulai dari hal yang kecil.

d. Barang/Jasa.

Memanfaatkan barang orang lain yang bisa kita kelola untuk berbisnis merupakan pemikiran seorang entrepreneur kreatif. Atau dengan memanfaatkan jasa yang bisa kita tawarkan pada orang lain, seperti : jasa menuliskan skripsi, jasa antar jemput. berikut:

Kegiatan pengabdian pada masyarakat ini dilakukan dengan tahapan sebagai

a. Tahap awal, yaitu dilaksanakannya observasi terhadap mahasiswa, pertemuan dengan UKM Kewirausahaan tentang kegiatan pengabdian mengenai program sportpreneurship. 
b. Tahap kedua, yaitu sosialisasi dan pelatihan mengenai pemberian sportpreneurship kepada mahasiswa.

c. Evaluasi untuk mengidentifikasi kekurangan dan kelebihan dalam pelaksanaan kegiatan kali ini, sehingga dapat dijadikan masukan pada kegiatan berikutnya. Setelah itu dilakukan penyusunan laporan dan proses administrasi penyampaian laporan kegiatan pada Lembaga Pengabdian Pada Masyarakat Universitas Jambi.

Dalam kegiatan pengabdian ini, langkah-langkah yang dilakukan adalah sebagai berikut:

a. Pemberian wawasan mengenai berfikir kreatif, inovatif dan visioner di era global, materi ini dimaksudkan untuk membekali peserta mengenai pentingnya berfikir kteatif, inovatif dan visioner serta agar peserta dapat membuka dan mengembangkan cakawala berfikirnya bahwa segala sesuatu apapun dapat dimanfaatkan menjadi peluang usaha apabila dapat membaca situasi dan kondisi yang ada disekitar.

b. Pemberian materi tentang gambaran umum sportpreneurship, materi ini dimaksudkan untuk membekali pengetahuan kepada peserta mengenai sportpreneurship. Isi yang disampaikan pada materi ini adalah mengenai makna dan hakikat sportpreneurship, langkah-langkah sportpreneurship, manfaat sportpreneurship bagi mahasiswa.

c. Pemberian wawasan mengenai potensi sportpreneurship sebagai peluang usaha, materi ini dimaksudkan agar peseta mengetahui dan memahami bahwa keterampilan dan kemampuan sportpreneurship dapat digunakan untuk memperoleh penghasilan sehingga dapat meningkatkan kesejahteraan pribadi, keluarga dan masyarakat secara umum.

d. Demonstrasi sportpreneurship yang diperagakan oleh instruktur (model) sehingga peserta dapat melihat secara langsung praktik, teknik, dan langkah-langkah dalam melakukan masasean sesuai dengan aturan yang baik dan benar.

e. Peserta mempraktekan ulang apa yang telah dilihat dan didengarnya kepada peserta yang lain secara bergiliran sehingga peserta dengan sendirinya akan mengetahui manfaat dari sportpreneurship.

f. Setelah peserta melakukan pelatihan sportpreneurship, maka instruktur membuka diskusi yang bermula dari pendapat pesera tentang perasaan yang dirasakannya, kemudian instruktur berdasarkan keterangan dari para peserta meluruskan apabila ditenggarai ada beberapa teknik, langkah yang tidak sesuai.

g. Menyusun rencana yang akan dilakukan setelah mengikuti pelatihan sportpreneurship, untuk mempermudah berjalannya usaha ini diharapakan dapat terbentuk komunitas sportpreneurship mahasiswa.

\section{HASIL DAN PEMBAHASAN}

Kegiatan pelatihan sportpreneurship sebagai peluang kewirausahaan ini diikuti oleh mahasiswa PORKES dan Kepelatihan Olahraga, Sentra Kewirausahaan Pemuda (SKP). Narasumber pada kegiatan pelatihan sportpreneurship sebagai peluang kewirausahaan adalah para pakar atau orang yang memiliki pengalaman antara lain pelaku usaha, HIPMI Kota Jambi. Dengan demikian output dari kegiatan ini memberikan informasi seluas-luasnya kepada mahasiswa tentang produk serta 
perkembangan usaha sehingga terjadi komuniksasi persuasif dalam rangka mendukung program pembinaan pemuda.

Dari kegiatan pelatihan sportpreneurship sebagai peluang kewirausahaan maka diperoleh sejumlah kesimpulan yang dapat dijadikan rekomendasi bagi kelembagaan kewirausahaan, antara lain:

a. Wirausaha muda agar bisa membuka lapangan pekerjaan dan bisa memberdayakan masyarakat disekitarnya.

b. Membuka kesempatan usaha terpulang bagi terdidik yang belum bekerja.

c. Memberikan kesempatan dan memfasilitasi para wirausaha muda untuk saling bertemu, sharing berbagi pengalaman dan memamerkan produk usaha masingmasing.

d. Memfasilitasi para wirausaha muda untuk dapat mempromosikan produk masingmasing dalam rangka mengembangkan usaha.

Kegiatan "Pelatihan sportpreneurship sebagai peluang kewirausahaan" sebaiknya sering dilakukan agar bisa memotivasi dan membekali mahasiswa ketika lulus kuliah tidak semata menjadi guru, melainkan menjadi wirausahawan. Melalui kegiatan juga mahasisswa bisa menciptakan lapangan pekerjaan ketika sudah lulus nantinya.

\section{KESIMPULAN}

Dari rangkaian kegiatan "Pelatihan sportpreneurship sebagai peluang kewirausahaan", maka dapat ditarik kesimpulan bahwa kegiatan ini sangat bermanfaat dalam membangkitkan semangat beriwausaha di kalangan peserta. Kegiatan ini dapat membuka wawasan bagi mahasiswa untuk bisa membuka lapangan pekerjaan.

\section{DAFTAR RUJUKAN}

Danial, Endang. 2010. Citizen Entrepreneurship Membina Warganegara yang Berkarakter Bisnis. Prosiding Seminar Pendidikan Pancasila dan Kewarganegaraan dalam Membangun Karakter Bangsa (Nation and Character Building) : Refleksi, Komitmen dan Prospek. Bandung : Laboratorium PKn Universitas Pendidikan Indonesia.

Kasmir. 2006. Kewirausahaan. Jakarta: PT Raja Grafindo Persada

Keputusan Menteri Koperasi dan Pembinaan Pengusahan Kecil Nomor 961/KEP/M/XI/1995

Longenecker, Justin G. 2000. Kewirausahaan Manajemen Usaha Kecil. Salemba Empat: Jakarta.

Suryana. 2004. Memahami Karakteristik Wirausaha. Jakarta : Direktorat Pendidikan Menengah Kejuruan Direktorat Jenderal Pendidikan Dasar dan Menengah Departemen Pendidikan Nasional

Suryana, 2010. Kewirausahaan, Pedoman Praktis, Kiat, dan Proses Menuju Sukses. Salemba Empat, Jakarta

Undang-undang No 3 Tahun 2005 Tentang Sistem Keolahragaan Nasional, 